\title{
Correction to: The relevance of anger, anxiety, gender and race in investment decisions
}

\author{
Daniel M. V. Bernaola ${ }^{1} \cdot$ Gizelle D. Willows ${ }^{2}$ (1) Darron West $^{1}$
}

Published online: 7 January 2021

(c) Springer-Verlag GmbH Germany, part of Springer Nature 2020

\section{Correction to: Mind \& Society https://doi.org/10.1007/s11299-020-00263-z}

The article "The relevance of anger, anxiety, gender and race in investment decisions", written by Daniel M. V. Bernaola - Gizelle D. Willows and Darron West, was originally published online on the publisher's internet portal on 21 October 2020 with Open Access under a Creative Commons Attribution 4.0 International License.

With the author's/authors' decision to cancel Open Access the copyright of the article changed on 19 November 2020 to (C) Springer Science+Business Media, LLC, part of Springer Nature 2020 with all rights reserved.

The original article was updated.

Publisher's Note Springer Nature remains neutral with regard to jurisdictional claims in published maps and institutional affiliations.

The original article can be found online at https://doi.org/10.1007/s11299-020-00263-z.

Gizelle D. Willows

gizelle.willows@uct.ac.za

1 Department of Finance and Tax, University of Cape Town, Cape Town, South Africa

2 College of Accounting, University of Cape Town, Cape Town, South Africa 